\title{
The Effect of Using Simulation Strategy in Developing English as a Foreign Language Speaking Skill
}

\author{
Mona M. Hamad \\ Department of English, College of Science \& Arts for Girls, Muhayil, King Khalid University, Saudi Arabia \\ Ehab S. Alnuzaili \\ Department of English, College of Science \& Arts for Boys, Muhayil, King Khalid University, Saudi Arabia
}

\begin{abstract}
Speaking skill acquisition is a necessity for communication. However, speaking English as a foreign language is not as easy as speaking English as a first language since practice opportunities are limited. This study tried to find out a technique of reinforcement that can help students; who study English as a foreign language; develop their speaking skills. This study investigated the effect of using simulation strategy in developing EFL speaking skills, with the assistance of using a telegram channel "Oxford Bookworms Collection" for PDF books with an audio version, to stimulate pronunciation, intonation and enrich vocabulary. The researchers used a quantitative approach with an experimental design to conduct this study by involving 50 students divided into two groups. 25 students as a control group and 25 students as an experimental group; both groups were from level 3 who were learning Listening and Speaking-3 course, major English, at College of Science and Arts (Muhayil), King Khalid University. Pretest and posttest were used to collect data, results of the tests were analyzed using SPSS, Pearson correlation coefficient. The results revealed that using the simulation strategy helped the students of the experimental group to develop speaking skills and affected speaking micro-skills in terms of body language, fluency, pronunciation, intonation, grammar, and vocabulary usage positively. Moreover, students became motivated to speak spontaneously.
\end{abstract}

Index Terms-effect, simulation strategy, EFL

\section{INTRODUCTION}

Since Adam's creation, children imitate their parents and people around them, copying their attitude, communication habits, speaking accents, body language, and even lifestyle. For communication, people use two methods of production, speaking and writing. Both skills are important, but speaking is more important for daily life. When people speak using their mother tongue, it is an easy task for them, as they are familiar to all factors that are associated with their language production.

Even Arab people who immigrated to European countries excel in English language and gain the accent of the people of those countries due to imitation of the people around them.

Speaking a mother tongue is not a problem. Since birth, everything around the speaker supports and helps develop speaking skills; children imitate their family members in speaking accent, tone, and body language. In other words, speaking mother tongue language is a kind of simulation to family members speaking habits and style. Simulation, according to Longman dictionary, is:

"the activity of producing conditions which are similar to real ones, especially to test something or the conditions that are produced."

But speaking a foreign language is not similar to speaking a mother tongue language; foreign language macro and micro-skills exposure need time and ability to connect them together in order to come out with correct phrases that reflect speaker's thoughts in a right way without interfering with their mother tongue rules. Shumin, K. (2002) stated that foreign language learning requires students to know how native speakers use the language in the context of structured interpersonal exchange, more than just knowing grammatical and semantic rules. He pointed out factors that affect adult learners' oral communication, such as the difficulties that face learners to use the language in social interactions. Using the right paralinguistic elements of speech like pitch, stress, and intonation or using other speaking skills that helped to convey the message while speaking, such: as gestures and body language/posture, facial expression.

Requirement associated with learning EFL mentioned by Shuimin cannot be done in Saudi Arabia, especially using the language in social interactions as the only place for the students to practice their EFL speaking skills is inside the classroom, following their teacher's instruction and simulating his/her pronunciation, intonation and body language in a fixed time, hardly enough to overcome the barriers that students face to speak spontaneously. Learning EFL in Saudi Arabia depends on lessons taken in the class with few supplementally exercises for practice. Speaking is regarded the most challenging skill for the students, they always avoid speaking in the class fearing mistakes or being a source of fun 
in front of their mates. Pradeep K. et al. (2020) identified that anxiety plays a major role in public speaking skills which can be overcome with a few simple strategies. Another factor that affects speaking skills is the time devoted to speaking skills practice is not enough to develop such important skill that learners need for everyday communication. Simulation can be one of these strategies that help to overcome anxiety.

Richards, J., \& Renandya, W. (2002) pointed that the highest percentage of learners in the whole world learn English to develop speaking proficiency, he illustrated how speaking a second or foreign language is a complex task .Speakers need speaking proficiency for different purposes such as: to establish rapport in conversations and requests, to chat with friends, for discussion, for persuading, for complaining... etc. . They pointed that linguists have provided information on speakers' usage of the language in different situation, and how to develop spoken fluency in a second or foreign language by clarifying the complex issues accompanied in developing spoken fluency.

It is the teacher responsibility to use the suitable method or techniques that suitable to help his/ her students develop their skills and achieve their pedagogical goal. Using the right teaching method or techniques is always the concern of teachers of (EFL) for a long time. They always try to enhance students to learning using all available supportive techniques to motivate students and decrease their anxiety towards learning.

Jones, R. (2002) pointed how the development of teaching methods affected pronunciation and revealed that today's activities are similar to the audiolingual text in 1950s, which leads to uncommunicative results in spite of the change of pronunciation teaching materials.

Many techniques and methods are used to develop speaking skills. In the past, the Audio Lingual Method is used to develop speaking for communication during the Second world War. But its drawbacks resulted in the appearance of other methods and techniques such as the Community Language learning and Communicative Language Teaching, which aimed at developing learners' speaking skills for communication. The problem that faces most educators in Arab countries is the lack of speaking practice. Students have no place to practice speaking except the class where most of them are reluctant to be active in dialogue and conversation inside the class fearing mistakes or being a source of ridicule for their mates which leads to students' anxiety.

So, using simulation may help to overcome these factors such as anxiety and make speaking an enjoyable task. Using simulation can help students practice their correct production of words' tone and accents. It can also help them develop their speaking skills by having a model for rehearsing different types of conversation, besides the confidence the students can gain by practice.

\section{OBJECTIVE OF THE STUDY}

As speaking skill is essential for everyday communication, the objective of this study is to find the effect of using simulation in developing English language speaking skill in terms of:
a- Body language and fluency.
b- Content and information sequence.
c- Pronunciation, intonation, grammar, and vocabulary usage.

\section{LITERATURE REVIEW}

The four skills of English language are listening, speaking, reading, and writing. Listening and reading are the input skills, while speaking and writing are the output skills. Nunan, D. (2002) claimed listening and reading are secondary skills for most people who want to learn a second language. Still, he pointed that listening is the cinderella skill in a second language, is associated with its elder sister, speaking. Being able to talk and write is a sign of claiming knowledge of a second or foreign language.

McCauley, S., \& Christiansen, M. (2019) stated that language acquisition usage is a computational model of language acquisition studies in moral growth fashion, based on chunking using online processing, to offer crosslinguistic coverage through merging comprehension aspects and production in a single framework.

Teaching speaking is not an easy task. It needs a lot of preparation to motivate students to speak spontaneously. McCarthy, M., and O'Keeffe, A. (2004) pointed six main areas relevant to the teaching of speaking: (1) spoken corpora influence growth, whether native speaker or non-native speaker, as it is based on data or successful user data / expert (2) the debates concerning native speaker (NS) and non-native speaker (NNS) models for spoken pedagogy which is clear in shifted shifts in methodology toward language-awareness-based approaches, as well as new materials based on lexicogrammatically and discoursal corpus evidence (3) the issue of authenticity in spoken materials, (4) approaches to understanding speaking in the classroom, including discourse analysis, conversation analysis, cognitive approaches, and the Vygotskian perspective (5) the selection of texts and aspects of spoken language for the teaching of speaking and it is application, and (6) developments in materials and methods for the teaching of speaking.

Teaching methods and techniques of English language are in continuous development to meet the pedagogical requirement that aim at developing the four English skills. When the Audio-Lingual Method ALM appeared, it aimed at developing speaking skills. Repetition of dialogues was a kind of simulation. Freeman, D. \& Anderson ( 2011) revealed that, the ALM aimed at helping communicate using stimuli to help students overcome habits of their native language to communicate using the target language through reinforcement and shaping learners to respond correctly to stimuli. 
One of the drawbacks of the ALM is that it turned learner to parrots, contributing little to the development of language competence, and resulting the introduction of other methods and techniques such as the Community Language Learning and the Communicative Language Teaching(CLT), Freeman, D. and Anderson(ibid ) pointed that Curran believed that CLT helped learners overcome their negative feeling during learning, and develop it to positive energy to reinforce their learning to have communicative competence which is the goal of most language teaching methods. Speaking is one of the most important ways to convey a message to a person or a group of people, Hebert, J. (2002) pointed out that speaking message are expressed through different language features such as: pitch variation and volume, stress and rhythm, intonation, so it is vital to learn phonology in context not separately, this beside content, grammar, structure, lexical items function skills, methodology and materials related to phonology, to speak effectively you need to be proficient in different element learned in language using various activities. Hamad (2013) points that students fear speaking in the class, and the classroom activities lack activities that support speaking, such as debates and roleplay. Hamad (2017) added that WhatsApp enhanced and helped students learning and develop their English language skills. Oflaz, A. (2019) indicated that language learning strategies affected academic achievement positively, he pointed that when shyness raises speaking anxiety appear; however, both shyness and anxiety can be relieved by learning strategies. Hamad \& Metwally (2019) highlighted that technology helped to promote teaching and learning, it also enhanced students' interaction skills students and help to overcome time and other learning problems that limit students' interaction. Maulina, Utami, et al., (2019) pointed out that using Sparkol VideoScribe in learning English in particular writing and speaking activities has a positive effect and helps students be attentive during learning .Laura \& Amparo (2019) reveal that simulation-based instruction contributes in developing oral language production and develop students micro skills such as grammar, pronunciation and vocabulary. ML Angelini \&A GarcĆa-Carbonell (2019) pointed how simulation helped students to progress in oral presentation, pronunciation, expression usage, using the correct grammar and speech fluency, showing that using simulation enhanced the students to research, learn, debate, negotiate, set forth proposals and make decisions. Hwang, et al. (2014) reveal that using activities on mobile learning system developed students speaking and listening skills and motivate students learning according to their proficiency levels. Al-Sobhi1 B\& Preece A (2018) Pointed that lack of teaching resources hinder teachers' abilities to develop students speaking skills, and on the students' side, he emphasized that overuse of Arabic beside students' lack of linguistic knowledge and confidence cause student's low performance. Arunget et al. (2020) discussed that sense of liking, which they called it "Preferent Learning Theory" affects students speaking performance, they revealed that students can learn without rules and formal evaluation. In other words, students can learn in unpredictable ways without any regulations and an informal self-evaluation. This application helped to sustain speaking skills when the students learn in their preferred ways. Vitthal ,G. (2010) explained some of the techniques which can be used in training institutions and the higher education pedagogy for developing speaking skills and improving language fluency such as: self-introduction activity, one-minute sessions, asking questions, giving directions, reading newspaper loudly, roleplay and simulation, situational dialogues, debates and group discussion Yeşilçınar, S.(2019) revealed that using flipped learning approach enhanced students speaking skills, and increased their motivation and satisfaction with flipped classroom model, it can be a reference to design oral skills of English Foreign language.

Saeed, Anmar H. (2017) suggested three controlled steps or stages to develop pronunciation and speaking fluency: 1. Repetition (mechanical stage) 2. Substitution activities (meaningful choices of items) 3. Communicative practice (using language within real). Hwang, W. Y et al. (2016) finding suggested that storytelling activity depends on story animations improved speaking skills, and developed learning achievement in final test, adding that it could help students to recall vocabulary when speaking to describe their animated stories. Eissa, H. M. S. (2019) revealed that Digital Story Telling not only motivated learners to speak English but also helped them develop their speaking skills. Digital Story Telling can assist teachers in Saudi Arabia in creating a conducive atmosphere in their classes.

\section{METHODOLOGY}

\section{A. Data Collection}

A quantitative experimental design was used to conduct this study to find out the effect of using simulation in developing learners English Foreign Language speaking skill. This is done by teaching two groups using the same method for 6 weeks, then taking a pretest, results were compared. Then one group is conducted using the same method, and the second group is taught by using simulation. In week 15, both groups took posttests; their results were coded and analyzed using SPSS.

\section{B. Participants}

The population of this study were students at College of Science \& Arts Muhayil, King Khalid University. The participants of this study were 50 students studying major English at level 3. Students were divided in two sections. 25 students in each section who have already learned two courses of listening and speaking. They were studying Listening and Speaking 3 in the $1^{\text {st }}$ semester of the Academic year 1440-1441

C. Instrument of the Study 
Speaking pretest and speaking posttest were used as instruments to collect data. Both sections; the control group and the experimental group; took the two tests. The tests tested different speaking skills such as: body language, fluency, pronunciation, intonation, grammar, vocabulary usage, content, and information sequence.

Reliability and Validity of the Test

To check the reliability and the validity of the test, the researchers used: Cronbach's Alpha., Spearman and Brown. The results demonstrate proved the validity of the test. See Table .1

TABLE 1

RELABILITY AND VALIDITY OF PRETESTS

\begin{tabular}{|l|l|l|}
\hline & Cronbach's Alpha & Spearman and Brown \\
\hline Reliable & 0.854 & 0.803 \\
\hline Validity $=\sqrt{\text { Reliable }}$ & 0.924 & 0.896 \\
\hline
\end{tabular}

The results in the table above display positive indicator. The validity and the reliability results qualify tests to be applied on the population of this study.

In order to ensure homogeneity between the experimental and control groups in the achievement level of Listening and Speaking-3 course, the scores of the experimental and control groups were monitored in the pretest before implementing the experiment on the sample members.

Independent Sample t-test was applied to identify any significant differences between the two groups. See Table .2

TABLE 2

THE HomogeneITy BetweEn The CONTROL AND THE EXPERIMENTAL Group IN THE PreTEST

\begin{tabular}{|l|l|l|l|l|l|l|}
\hline Group & Mean & Std. Deviation & t & df & Sig. (2-tailed) & Reality of 0.05 \\
\cline { 1 - 5 } Experimental group & 7.5400 & 1.49944 & 1.511 & 48 & .137 \\
\cline { 1 - 3 } Control group & 6.9400 & 1.30160 & & \\
\end{tabular}

It is clear from the Table .2 that " $t$ " value (1.511) and (2-tailed) value (.137) which is insignificant at reality of (,05) which means there is no significant statistical difference between the two groups,and reflecting the homogeneity between the experimental and control groups.

\section{Study Design}

Two sections of students are the participants of this study. Both sections are studying major English level 3 . One section is used as a control group and the second is used as experimental group. Both sections were taught using traditional strategies of teaching listening and speaking using roleplay, free discussion, pair work and groupwork to help students speak after listening to the audio tracks for six weeks. The two groups sat for the pretest. After that the control group continued learning with a traditional strategy, but the experimental group was taught using simulation strategy. 10 minutes at the end of each lecture is used to display the PDF book "Jane Eyre" with the projector associated with audio for the story picked from "bookworm collection, telegram channel". Some students practiced reading paragraphs imitating the narrator and the speakers in the story, trying to copy accent and intonation using their body language. Students used to listen to the story on their way to college. In week 12, students of the two groups took the same posttest. A speaking assessment sheet was designed to test students' speaking skill for both pretest and posttest testing three terms:

1- $\quad$ Body language and fluency. (3marks)

2- $\quad$ Content and information sequence. (4 marks)

3- $\quad$ Pronunciation, intonation, grammar, and vocabulary usage. (3marks)

The results of the two tests are analyzed to find out the effect of using simulation in developing English language speaking skill. 


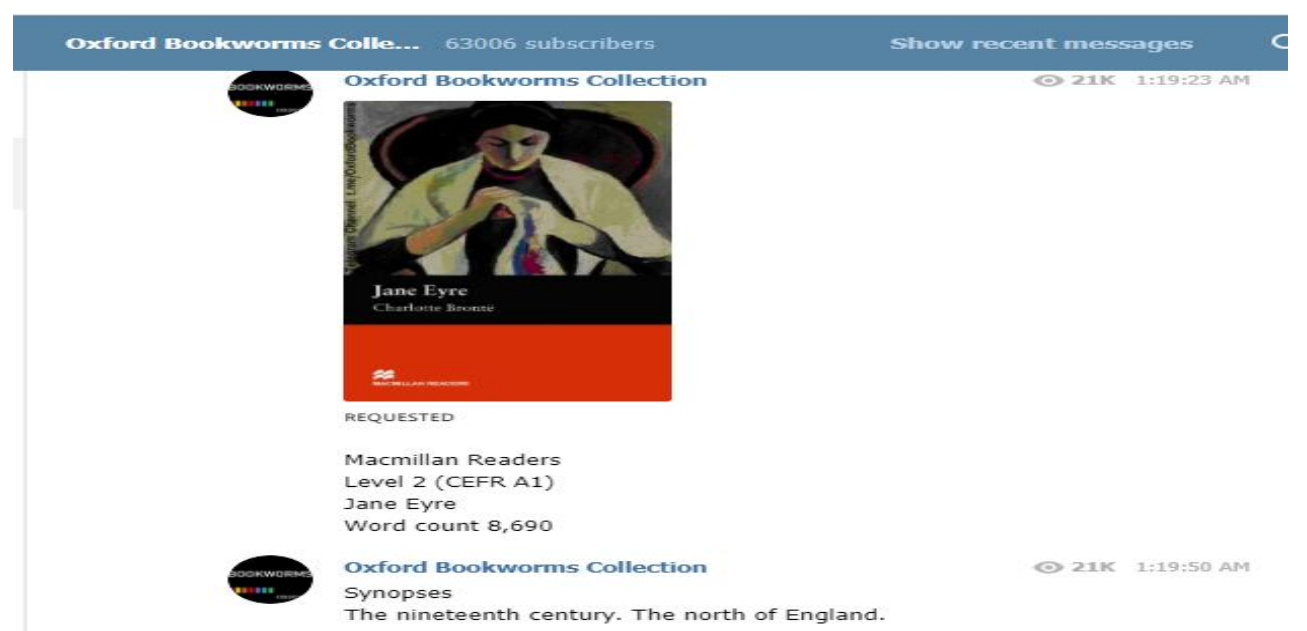

Figure. I Jane Eyre in Oxford Bookworms collection

Source : Oxford Bookworms Collection, retrieved on Aug 21, 2020 from https://t.me/OxfordBookworms

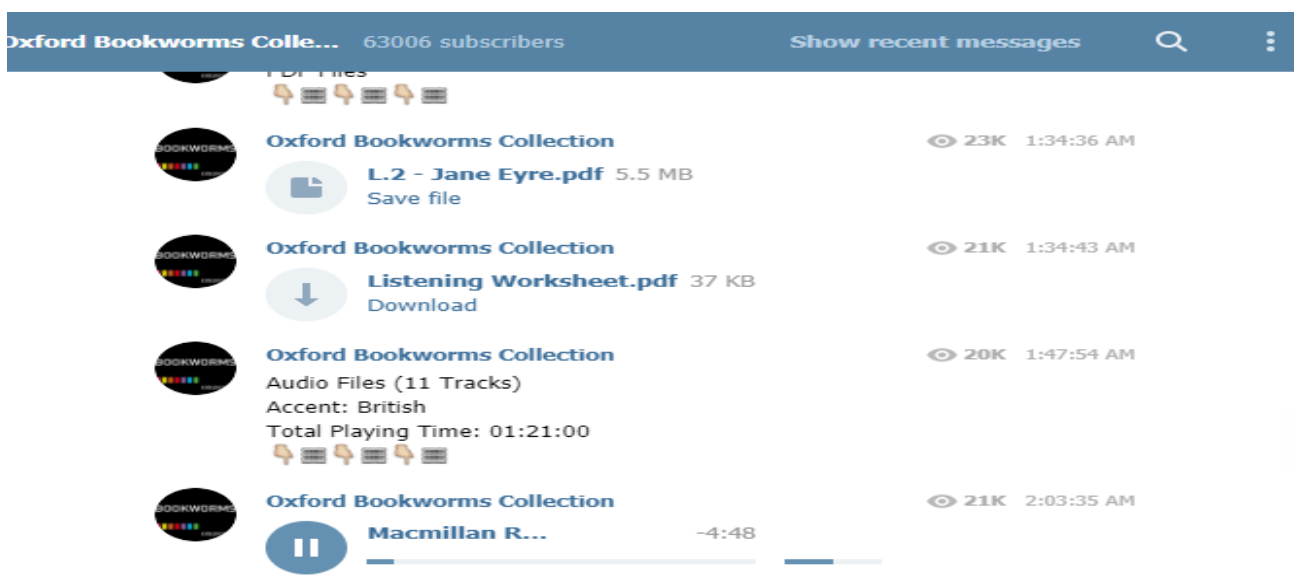

Figure. II Jane Eyre audio playing in Oxford Bookworms collection

Source : Oxford Bookworms Collection, retrieved on Aug 21, 2020 from https://t.me/OxfordBookworms

\section{Statistical and Analytical Results}

After the sixth weeks from the pretest, and displaying the audio stories in the class for ten minutes in each lecture of 60 minutes, students sat for a posttest. Results of the post-test for the two groups were analyzed using SPSS to find out the effectiveness of using simulation in developing English language speaking skill in term of a- Body language and fluency. b-Content and information sequence. c-pronunciation, intonation, grammar, and vocabulary usage.

To compare using simulation strategy on students' achievement of the experimental group, to using the traditional strategy on the control group, the researcher applied a ( $t$ ) test to find the average of the two independent groups in terms of "Body language and fluency". Table .3 illustrates the results of this procedure:

TABLE 3

EXPERMINTAL AND CONTROLLED GROUP DIFFERENCES IN TERM OF BODY LANGUAGE AND FLUENCY

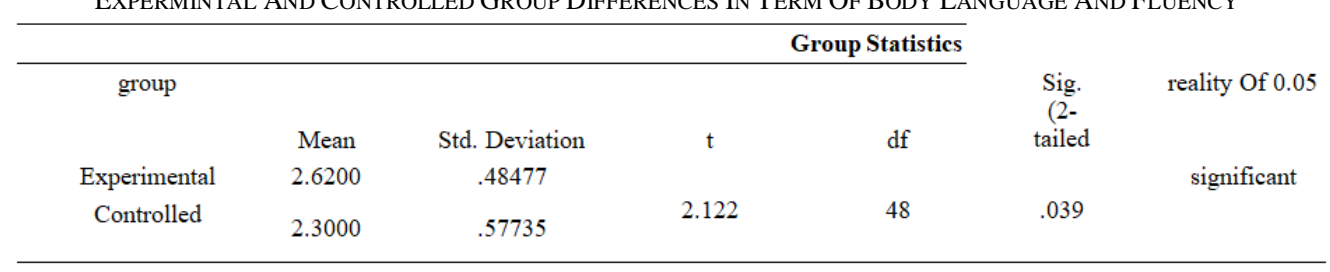

Seeing Table .3 above, it is clear from the results that the value of $(t)$ calculated (3.777) with a degree of freedom (48) and a probability value $(0.000)$, which means that there are statistically significant differences between using the simulation strategy and the traditional strategy on students' achievement of speaking skill in term of body language and fluency, results are in favour of the experimental group that learned by using simulation strategy at level of $(0.05)$. 
To find the difference between the two independent groups achievement in speaking skill in term of "content and information sequence" after using simulation strategy, the researchers applied a ( $\mathrm{t}$ ). test to find the average of the two independent groups. Table .4 illustrates the results of this procedure:

TABLE 4

DIFFERENCES BETWEen EXPERIMENTAL AND CONTROLLED GROUP IN TERMS OF CONTENT AND INFORMATION SEQUENCE

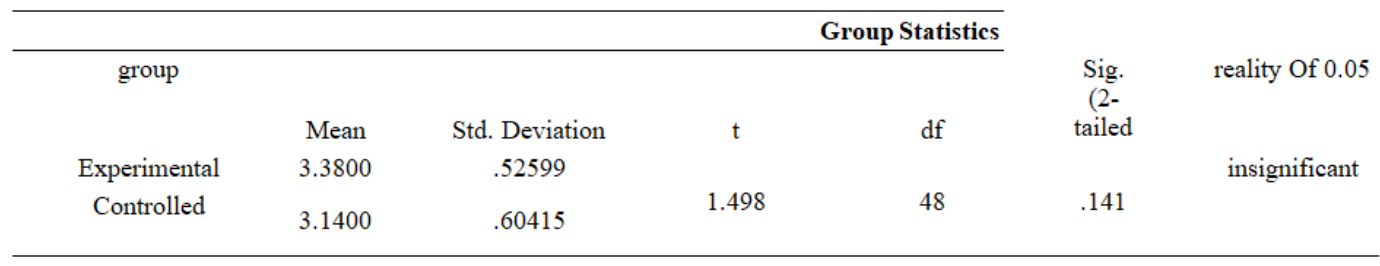

Seeing Table .4 above, it is clear from the results that the value of $(\mathrm{t})$ was calculated (1.498) with a degree of freedom (48) and a probability value (.141), which means the results are statistically insignificant at reality level of (0.05). Hence there are no clear differences between using the simulation strategy and the traditional strategy on students' achievement of speaking skill in in terms of content and information sequence significance.

Inspecting difference between the two independent groups' achievement in speaking skill in terms of "pronunciation, intonation, grammar and vocabulary usage" after using simulation strategy and the traditional strategy, the researchers applied a ( $\mathrm{t}$ ). test to calculate the average of the two independent groups. Table .5 illustrates the results of this procedure:

TABLE 5

DIFFERENCES BETWEEN EXPERIMENTAL AND CONTROLLED GROUPS IN TERMS OF "PRONUNCIATION, INTONATION, GRAMMAR AND VOCABULARY USAGE"

\begin{tabular}{|c|c|c|c|c|c|c|}
\hline & & & & Group Statistics & & \\
\hline group & Mean & Std. Deviation & $\mathrm{t}$ & df & $\begin{array}{c}\text { Sig. } \\
(2- \\
\text { tailed }\end{array}$ & reality Of 0.05 \\
\hline Experimental & 2.6200 & .48477 & & & & significant \\
\hline Controlled & 2.3000 & .57735 & 2.122 & 48 & .039 & \\
\hline
\end{tabular}

Seeing Table .5 above, it is clear from the results that the value of $(\mathrm{t})$ came to be (2.122) with a degree of freedom (48) and a probability value (.039), which means that the results are significant. There are statistical differences between using the simulation strategy and the traditional strategy on students' achievement of speaking skills in terms of pronunciation, intonation, grammar and vocabulary usage. The results are in favour of the experimental group taught by using simulation strategy at a reality level of (0.05).

To find the difference between the two independent groups' achievement in speaking skill in total results of the students covering the three terms: a-body language and fluency. b-content and information sequence. c. pronunciation, intonation, grammar, and vocabulary usage; after using simulation and traditional strategies, the researchers applied a (t). test to find the average of the two independent groups in total. Table .6 illustrates the results of this procedure:

TABLE 6

DIFFERENCES BETWEEN EXPERMINTAL AND CONTROLLED GROUP IN TERM OF TOTAL RESULTS

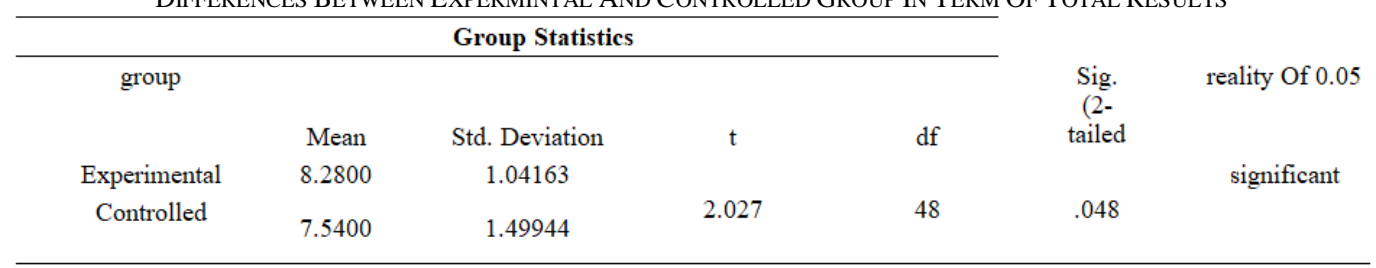

Looking at table .6 above, it is clear from the results that the value of $(\mathrm{t})$ calculated (2.027) with a degree of freedom (48) and a probability value (.048), which means that there are statistically significant differences between using the simulation strategy and the traditional strategy on students' achievement of speaking skill in total. Results are in favour of the experimental group which was taught by using the simulation strategy at a reality level of (0.05).

\section{DisCUSSION OF RESUlTS}

Speaking English as a foreign language in a fluent way is regarded the biggest challenge that faces Arab learners. This study was conducted to find the effect of using simulation on Arab learners EFL speaking micro skills such as: pronunciation, intonation, grammar, using of vocabulary and fluency. Researchers of this study tried to do that by using audio tracks embedded with a PDF transcript of Jane Eyre story of 11 chapters. It was downloaded from Oxford Book Worms -Telegram Channel, as mentioned in the study design. 
The results of the analysis proved that listening to audios while following up the transcript developed students' speaking skill achievements of the experimental group, as their results were better than those of the control group in terms of using body language, intonation, accent and fluency.

Coping the narrator and characters of the story in tone, accent and intonation is a kind of simulation to the storyspeakers. Simulation helped students produce similar speaking model of sadness, happiness, etc. whenever they come across similar situation. This solved the problem of students' little practice opportunity to speaking in class. Simulation here served as backbone for correct speaking production, beside the students' high motivation which was observed during listening and simulating speakers of the story-audio within students own time, this action became a selfintroduction activity, as Vitthal ,G. (2010) pointed. This finding also supports results of Hamad (2013) and Hamad (2017) which show that roleplay helped to develop speaking and using telegram channel here enhanced students' listening and speaking skills. Using simulation can be an active technological strategy to promote teaching as Hamad \& Metwally (2019) pointed. Simulation using technology can be a helpful teaching strategy to decrease students' anxiety and develop speaking skill as also Oflaz, A. (2019), Maulina, Utami, et al , (2019) and Vitthal ,G. (2010) pointed.

Comparing students results analysis of the two groups, the experimental group and the control group regarding the effect of simulation on content and information sequence while speaking "see table 4" after taking posttest showed that, there was no different between the students in both group in choosing content and information sequence in their speech.

Pronunciation, intonation, grammar, and vocabulary usage constituted the third part in the assessment sheet of the students' speaking tests. The results proved that students' development in pronunciation, intonation, grammar and vocabulary usage were in favour of the experimental group who learned with simulation strategy. So simulation can be used as a teaching strategy to affect students speaking skill positively, this beside having the telegram channel in students mobile phones increased students chance of listening, practice and repetition which later developed their speaking proficiency level. as Hwang, et al. (2014) revealed. Finding also agreed with Saeed, Anmar three suggested controlled steps or stages for developing pronunciation, and Laura and Amparo (2019) who pointed that simulation based instruction contributes in developing oral production.

Comparing speaking total results in the assessment sheet of the two groups were in favour of the experimental group. Students who learned using simulation strategy got higher marks, that reflected the positive influence of simulation on students speaking skills. Simulation usage reinforced students' fondness to listening and then speaking as well, so results showed how these two skills can be posted by using simulation strategy.

When educators solve students' preference, their interest will be posted, and when students' interest is posted then their learning outcomes can be achieved. Students' freedom to access and read different books according to their preference motivated and helped them learn better as Arung, et al. (2020) discussed. Results also agreed with Eissa, H. M. S. (2019) and Hwang, W. Y et al (2016) regarding the use of stories in developing speaking skill. Having different materials with easy access helped the students to relisten to the story as many times as they need, till they are satisfied, this also agreed with Saeed, Anmar H. (2017) steps.

\section{CONCLUSION}

Speaking EFL is the most important skill for communication, simulation can help to develop students speaking skill in terms of body language and fluency, pronunciation, intonation, grammar and vocabulary usage. In general it affected speaking skill positively, and can be an adapted strategy to Audio-Lingual Method. Making use of the advantages of Audio-Lingual Method and overcoming all its drawbacks. Using the assistance of technology and phone Apps, helped the students to overcome their low practice opportunities and enhanced their learning.

Using simulation will help educators introduce other strategies that can develop EFL different skills in general and speaking skill in specific. Simulation motivated students to develop their speaking skills that suit their interests and decrease anxiety associated with speaking practice. It also made the students able to overcome their first language habit. Simulation helped to fill all gaps related to teaching speaking skills as EFL.

\section{REFERENCES}

[1] Al-Sobhi1, B\& Preece, A. (2018). Teaching English speaking skills to the Arab students in the Saudi school in Kuala Lumpur Problems and Solutions, International Journal of Education \& Literacy Studies, $6 \quad$ (1) 32-43. http://dx.doi.org/10.7575/aiac.ijels.v.6n.1p.1

[2] Arung ,F.., Rafli, Z. \& Dewanti, R. (2020). I prefer my own ways to acquire my English speaking Skills: A grounded research, International Journal of Higher Education, 9 (1) 32- 43. https://doi.org/10.5430/ijhe.v9n1p32

[3] Bronet, C, Jane Eyre. Oxford Bookworms Collection, telegram Channel, Macmillan readers, beginner level retrieved on Sep, 26,2021 from https://t.me/OxfordBookworms

[4] Eissa, H. M. S. (2019). Pedagogic effectiveness of digital storytelling in improving speaking skills of Saudi EFL learners. Arab World English Journal, 10 (1) 127-138.https://dx.doi.org/10.24093/awej/vol10no1.12

[5] Freeman, D. \& Anderson. (2011). Techniques \& principles in language teaching, Oxford University Press, $3^{\text {rd }}$ edition

[6] Hamad, M. (2013). Factors negatively affect speaking skills at Saudi colleges for girls in the South, English Language Teaching. 6, (12).87-97 https://dx doi:10.5539/elt.v6n12p87

[7] Hamad, M. (2017). Using WhatsApp to enhance students' learning of English language, experience to share, Higher Education Studies Journal, 7, (4) 74-84 https://dx.doi.org/10.5539/hes.v7n4p74 
[8] Hamad ,M. M., \& Metwally, A. A. (2019). Using technology towards promoting online instructional scaffolding: Literature review. Arab World English Journal, Special Issue:The Dynamics of EFL in Saudi Arabia. 85-95 https://dx.doi.org/10.24093/awej/efl1.7

[9] Hebert, J. (2002). PracTESOL: It's not what you say, but how you say it! In J. Richards \& W. Renandya (Eds.), Methodology in Language Teaching: An Anthology of Current Practice (Cambridge Professional Learning, pp. 188-200). Cambridge $\begin{array}{lllllll}\text { University } & \text { Press. } & \text { retrieved } & \text { Sep } & 26 & \text {, } & 2021\end{array}$ https://viancep2012.files.wordpress.com/2011/12/methodology_in_language_teaching_2002_scanned.pdf

[10] Hwang, W.-Y., Huang, Y.-M., Shadiev, R., Wu, S.-Y., \& Chen, S.-L. (2014). Effects of using mobile devices on English listening diversity and speaking for EFL elementary students. Australasian Journal of Educational Technology, 30(5). retrieved on Sep 26,2021 from https://doi.org/10.14742/ajet.237

[11] Hwang, W. Y., Shadiev, R., Hsu, J. L., Huang, Y. M., Hsu, G. L., \& Lin, Y. C. (2016). Effects of storytelling to facilitate EFL speaking using web-based multimedia system, Computer Assisted Language Learning 29.(2) 215-241 retrieved on Sep 26,2021 from https://doi: 10.1080/09588221.2014.927367

[12] Jones, R. (2002). Beyond Listen and repeat': Pronunciation teaching materials and theories of second language acquisition. In J. Richards \& W. Renandya (Eds.), Methodology in Language Teaching: An Anthology of Current Practice (Cambridge Professional Learning, pp. 178-187).: Cambridge University Press. retrieved on Sep 26 ,2021 from https://viancep2012.files.wordpress.com/2011/12/methodology_in_language_teaching_2002_scanned.pdf

[13] Laura,M..A \& A,G.G. (2019). Developing English speaking skills through simulation -based instruction. Teaching English with Technology, 19(2), 3-20, retrieved on Sep 26,2021 from https://files.eric.ed.gov/fulltext/EJ1215381.pdf

[14] Longman Dictionary of Contemporary English. retrieved on Sep 26 ,2021 from https://www.ldoceonline.com/dictionary/simulation

[15] Maulina, Utami, et al. (2019). Attractive learning media to cope with Students' Speaking Skills in the industry 4.0 Using Sparkol Videoscribe ." International Journal of Linguistics, Literature and Translation, 2, (5) 132-140. retrieved on Sep 26,2021 from https://doi:10.32996/ijllt.2019.2.5.15.

[16] McCarthy, M., \& O'Keeffe, A. (2004). 2. Research in the teaching of. Annual Review of Applied Linguistics, $24,26-43$. retrieved on Sep 26,2021 from https://doi:10.1017/S0267190504000029

[17] McCauley, S. M., \& Christiansen, M. H. (2019). Language learning as language use: A cross-linguistic model of child language development. Psychological Review, 126(1), 1-51. retrieved on Sep 26,2021 from https://doi.org/10.1037/rev0000126

[18] ML Angelini \&A GarcĆa-Carbonell. (2019). Developing English Speaking skills Through Simulation -Based Instruction, Teaching English with Technology, 19(2), 3-20.

[19] Nunan, D. (2002). Listening in language learning. In J. Richards \& W. Renandya (Eds.), Methodology in Language Teaching: An Anthology of Current Practice(Cambridge Professional Learning, pp. 238-241) Cambridge University Press. retrieved on Sep 26 ,2021 from: https://viancep2012.files.wordpress.com/2011/12/methodology_in_language_teaching_2002_scanned.pdf

[20] Oflaz, A. (2019). The effects of anxiety, shyness and language learning strategies on speaking skills and academic achievement. European Journal of Educational Research, 8(4), 999-1011. retrieved on Sep 26 ,2021 from https://doi.org/10.12973/eujer.8.4.999

[21] Oxford Bookworms Collection retrieved on Sep 26,2021 from https://t.me/OxfordBookworms

[22] Pradeep Kumar Sahoo, Smita ,Sinha. (2020). " Role of anxiety in speaking skills: An exploratory study" Language in India, 20, (2) 58-61. retrieved on Sep 26,2021 from http://www.languageinindia.com/feb2020/sahoospeakinganxietyfinal.pdf

[23] Richards, J., \& Renandya, W. (2002). Teaching speaking. In J. Richards \& W. Renandya (Eds.), Methodology in Language Teaching: An Anthology of Current Practice (Cambridge Professional Learning, pp. 201-203). Cambridge University Press. retrieved on Sep 26,2021 from https://doi.org/10.1017/CBO9780511667190.027

[24] Saeed, Anmar H. (2017). Developing fluency in the pronunciation of Iraqi Learners of English: Method and Techniques Journal of Kirkuk University Humanity Studies. 12 (2) 23-51.

[25] Shumin, K. (2002). Factors to consider: Developing adult EFL Students' speaking abilities. In J. Richards \& W. Renandya (Eds.), Methodology in Language Teaching: An Anthology of Current Practice, pp. 204-211:Cambridge University Press retrieved on Sep 26,2021, from https://doi.org/10.1017/CBO9780511667190.028

[26] Vitthal ,G. (2010). Techniques for developing speaking skills and fluency, The IUP Journal of Soft Skills, 4 (1 \& 2 ) 7-17, $\begin{array}{lllll}\text { retrieved } & \text { on } & \text { Sep } & 26 & \text {,2021 }\end{array}$ http://kangnamjoon.weebly.com/uploads/1/3/6/7/13673728/techniques_for_developing_speaking_skills_(1).pdf

[27] Yeşilçınar, S. (2019). Using the flipped classroom to enhance adult EFL learners' speaking skills, PASAA, Journal of Language Teaching and Learning in Thailand, 58, 206-234 retrieved on Sep 26 ,2021, from https://eric.ed.gov/contentdelivery/servlet/ERICServlet?accno=EJ1227386

Mona M. Hamad is a Sudanese, her Ph.D. in Education "Curriculum \& Teaching Methods of English Language" from AlZaiemAzhhri University, Khartoum, Sudan. She obtained her master's degree in Education Technology (2005) from Al-ZaiemAzhhri University, Khartoum, Sudan. She also obtained a higher degree Diploma in ELT (2001) from Khartoum University, Khartoum, Sudan. Her Bachelor of Arts (1991) was obtained from AL-Neelain University, Khartoum, Sudan.

She has been working as Assistant Professor at King Khalid University, Muhayil, English Department since 2012. She has worked as Part-time Assistant Professor for Al-ZaiemAzhhri University, Sudan, Khartoum from 2010-2012; she also worked as English language teacher for Secondary level for the Ministry of General Education, Sudan, Khartoum from 1996-2012 .

She published many papers and two books. Dr. Mona M. Hamad is a member of KSAALT /TESOL (Kingdom of Saudi Arabia Association of English Language Teachers) \& ASTEL (Association of Sudanese Teachers of English Language). 


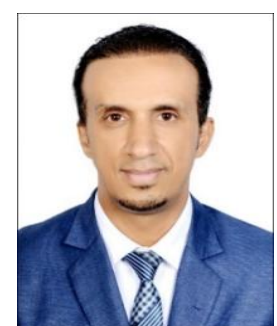

Ehab Alnuzaili was born in Ibb Town (Yemen) in 1981. While he received his BA in English from Ibb University (Yemen), he pursued his $\mathrm{MA}$ and $\mathrm{PhD}$ at the Centre for Applied Linguistics and Translation Studies of the University of Hyderabad (Hyderabad, India). Specialized in applied linguistics, he obtained his MA in 2011 and PhD in 2013.

$\mathrm{He}$ is now an Assistant Professor at the College of Science and Arts (Muhayil Aseer), King Khalid University (KSA). Earlier, he worked for about a decade at the National Institute for Administrative Science (Ibb, Yemen). The main research areas of interest include ELT, applied linguistics, translation studies, teaching Arabic for foreign learners, and English for non-native speakers.

Dr. Alnuzaili is an active member of the organizing committee of Tehama Annual Scientific Conference. His hobbies include director assistant of college registration and technician for global football. 